\title{
The microbial community in the coastal upwelling system off Concepción, Chile, $36^{\circ} \mathrm{S}, 2002-2003$ period
}

\author{
La comunidad microbiana en el sistema de surgencia costero de Concepción, \\ Chile, $36^{\circ} \mathrm{S}$, periodo $2002-2003$
}

\section{Yoanna Eissler ${ }^{1,2}$, Jaime Letelier ${ }^{3,4}$, L. Antonio Cuevas ${ }^{5}$, Carmen E. Morales ${ }^{6}$ and Rubén Escribano ${ }^{6}$}

\author{
${ }^{1}$ Centro de Investigación y Gestión de Recursos Naturales, Departamento de Química y Bioquímica, Facultad de Ciencias, \\ Universidad de Valparaíso, Gran Bretaña 1111, Valparaíso, Chile \\ ${ }^{2}$ CIEN Austral, Centro de Investigación en Nutrición, Tecnología de Alimentos y Sustentabilidad, Universidad Austral \\ de Chile, Los Pinos S/N, Balneario Pelluco, Casilla 1327, Puerto Montt, Chile \\ ${ }^{3}$ Programa de Postgrado en Oceanografía, Universidad de Concepción, Casilla 160-C, Concepción, Chile \\ ${ }^{4}$ Escuela de Ciencia del Mar, Pontificia Universidad Católica de Valparaíso, Av Altamirano 1480, Valparaíso, Chile \\ ${ }^{5}$ Department of Biology, University of Bergen, Thormøhlens gate 53, PO Box 7003, N-5020 Bergen, Norway \\ ${ }^{6}$ Centro de Investigaciones Oceanográficas del Pacífico Sur-Oriental (COPAS), Estación de Biología Marina, \\ Departamento de Oceanografía, Universidad de Concepción, Casilla 44, Dichato, Chile \\ yoanna.eissler@uv.cl
}

Resumen.- Este estudio describe la abundancia y distribución vertical de ensambles microbianos (desde femto a nanoplancton) en el área de surgencia de Concepción $\left(\sim 36^{\circ} \mathrm{S}\right)$, analiza su relación con las condiciones oceanográficas durante la estación de surgencia (primavera-verano austral: diciembre 2002-marzo 2003), y explora las interrelaciones de la comunidad microbiana; en una estación ubicada en la plataforma continental de la costa este del Pacífico sudamericano y otra en el quiebre de esta plataforma. Virioplancton (VP), bacterioplancton (BP) y nanoflagelados autotróficos (ANF) y heterotróficos (HNF) fueron enumerados por medio de microscopia de epifluorescencia. Las abundancias de VP, BP, HNF y ANF presentaron los siguientes rangos: $0,04-$ $13,9 \times 10^{7}$ partículas virales $\mathrm{mL}^{-1}, 0,5-5,6 \times 10^{6}, 0,016-0,4 \mathrm{x}$ $10^{3}$, y $0,08-0,6 \times 10^{3}$ cél. $\mathrm{mL}^{-1}$, respectivamente. La variabilidad en la abundancia de VP, BP y HNF fue explicada en menos del $27 \%$ por las condiciones oceanográficas (i.e. temperatura, salinidad y oxígeno disuelto). Las condiciones de surgencia tienen un efecto sobre la distribución y abundancia sólo del VP en las dos estaciones examinadas. La abundancia del VP estuvo significativa y positivamente relacionada con las abundancias del BP, ANF y HNF, lo que sugiere que podrían ser posibles hospedadores de virus marinos. Además, la razón $\mathrm{VP} / \mathrm{BP}$ (promedio $=9$ ) presentada, representa el límite superior en los valores de la literatura, lo que sugiere un alta interacción entre virioplancton y bacterioplancton.

Palabras clave: Virus, bacterioplancton, nanoplancton, ensambles microbianos

\begin{abstract}
This study describes the abundance and vertical distribution of microbial assemblages (from femto to nanoplankton) in the upwelling area off Concepción $\left(\sim 36^{\circ} \mathrm{S}\right)$, analyses their relationship to oceanographic conditions during the upwelling season (austral spring-summer: December 2002March 2003), and explores microbial community interrelationships; at one shelf station and at the shelf break off the Southeastern Pacific coast. Virioplankton (VP), bacterioplankton (BP), and autotrophic (ANF) and heterotrophic (HNF) nanoflagellates were enumerated by epifluorescence microscopy. Abundances of VP, BP, HNF and ANF ranged as follows: 0.04-13.9 $\times 10^{7}$ virus like particles $\mathrm{mL}^{-1}, 0.5-5.6 \times 10^{6}, 0.016-0.4 \times 10^{3}$, and $0.08-0.6 \times 10^{3}$ cells $\mathrm{mL}^{-1}$, respectively. Variability in VP, BP and HNF abundance was explained in less than $27 \%$ by the oceanographic setting (i.e. temperature, salinity and dissolved oxygen). Upwelling conditions have a significant effect on distribution and abundance only of VP in both station examined. VP abundance was significant and positively related to the abundances of BP, ANF and HNF, suggesting that they may be possible hosts of marine viruses. Furthermore, the VP/BP ratio (mean $=9$ ) obtained represented the upper limit of literature values, suggesting a high interaction between virioplankton and bacterioplankton.
\end{abstract}

Key words: Viruses, bacterioplankton, nanoplankton, microbial assemblages 


\section{Introduction}

A large proportion of the total flux of matter and energy in marine food webs is channelled through microorganisms, the microbial loop concept (multiple trophic levels and high nutrient recycling) have been developed and reinforced during the last two decades (reviews in Azam 1998, Gasol \& Duarte 2000, Cotner \& Biddanda 2002). Marine viruses play a relevant role in the microbial food web, they are the most abundant organisms in the ocean, with concentrations from $10^{6}$ to $10^{8}$ viruses $\mathrm{mL}^{-1}$ (e.g. Bergh et al. 1989, Proctor \& Fuhrman 1990, Hara et al. 1991, Wommack et al. 1992). They have the potential to infect all organisms from bacteria to whales (Munn 2006), producing mortality and cell lysis of their hosts. Therefore they have been recognised to be a relevant component of microbial assemblages and a controlling agent of micro-organism abundances and diversity, thereby having biogeochemical and ecological impacts on marine systems (Fuhrman 1999, Wommack \& Colwell 2000, Suttle 2005, 2007). However, in the majority of microbiological studies carry out in the Southeastern Pacific marine viruses have not been addressed as part of the microbial community, thus their potential effects are poorly understood in this vast area of the ocean.

The relative importance of microbial communities to biogenic fluxes is thought to be maximized in oligotrophic, low-productivity systems and diminished in eutrophic, high-productivity waters. In absolute terms, however, microbial abundance and activity are comparatively higher in the latter (Cotner \& Biddanda 2002). Among the most productive ecosystems are the upwelling systems in the eastern boundaries of the oceans (i.e. the California Current System, the Benguela Upwelling System, and the Humboldt Current System) that have commonly being viewed as governed by a short food chain, which comprises large sized phytoplankton and zooplankton, and small pelagic fish. Studies carried out in the Humboldt Current System have questioned the simplicity of this view and have emphasised a strong coupling between bacterial and algal production through the dissolved organic matter (Sorokin 1978, Brown et al. 1991, Painting et al. 1993, Troncoso et al. 2003, Cuevas et al. 2004). Nevertheless, little is known on the abundances and role of other microbial components in the transformations and transfer of biogenic elements in the upper water column and/or on the main processes controlling bacterial abundance (i.e. bacterivory, viral lysis) in this upwelling system.

The Humboldt Current System goes from $\sim 42^{\circ} \mathrm{S}$ up to about the equator (Montecino et al. 2006), presenting cold, low in oxygen content and rich in nutrients waters, that are frequently upwelled to the surface along the Southeastern Pacific coast. The low oxygen concentrations are associated with the Equatorial Subsurface water mass (ESSW) (Sievers \& Silva 1982, Silva 1983) that is often a source of coastal upwelling water that fertilize the surface layer due to its high nutrient content (Morales et al. 1996). The main upwelling centers along Chilean coast are: Mejillones, Antofagasta, Coquimbo, Concepción and Arauco Gulf that are centers of pelagic fisheries and high primary production (review in Thiel et al. 2007). Off Concepción ( $\left.36^{\circ} \mathrm{S}\right)$, upwelling is strongly seasonal (austral spring-summer) and influences an extensive area (over a wide shelf $\sim 70 \mathrm{~km}$ ). High values of phytoplankton biomass $\left(>5 \mathrm{mg} \mathrm{m}^{-3}\right)$ and primary production rates $\left(4-9 \mathrm{~g} \mathrm{C} \mathrm{m}^{-2} \mathrm{~d}^{-1}\right)$ are found during these events (Daneri et al. 2000). Estimates of bacterial production, abundance and biomass have suggested that an important fraction of the organic matter produced by phytoplankton is channelled through the bacteria (McManus \& Peterson 1988, Troncoso et al. 2003, Cuevas et al. 2004, Vargas et al. 2007) and, afterward, through heterotrophic nanoflagellates (Cuevas et al. 2004), in consequence, microbial food webs have a central role cycling carbon in the upwelling system off Concepción.

The present study goes one step further studying whether viruses among the microbial components could be playing an important role in the upwelling system off Concepción. Here we present direct counts of total VP, $\mathrm{BP}, \mathrm{HNF}$ and ANF as a function of depth in the water column and distance from shore in a coastal and shelf break station off Concepción during an upwelling period. Biomass of the different microbial components and chlorophyll- $a$ biomass is also reported, as well as the oceanographic conditions (i.e. salinity, temperature, dissolved oxygen content, wind direction/velocity) presented in the area. The objective of this study is analyze the relationships of VP abundance/biomass to BP, HNF, ANF, chlorophyll- $a$ abundance/biomass, and their association with the oceanographic conditions during the upwelling season. In addition, the implications of marine viruses as parasites of BP, HNF and ANF are discussed.

\section{Material and methods}

\section{Study area and sampling procedure}

Samples were collected in the area off Concepción (Fig. 1), as part of a time series study initiated by the COPAS Center (2002), and covered the upwelling season (austral spring-summer). All sampling was carried out onboard 


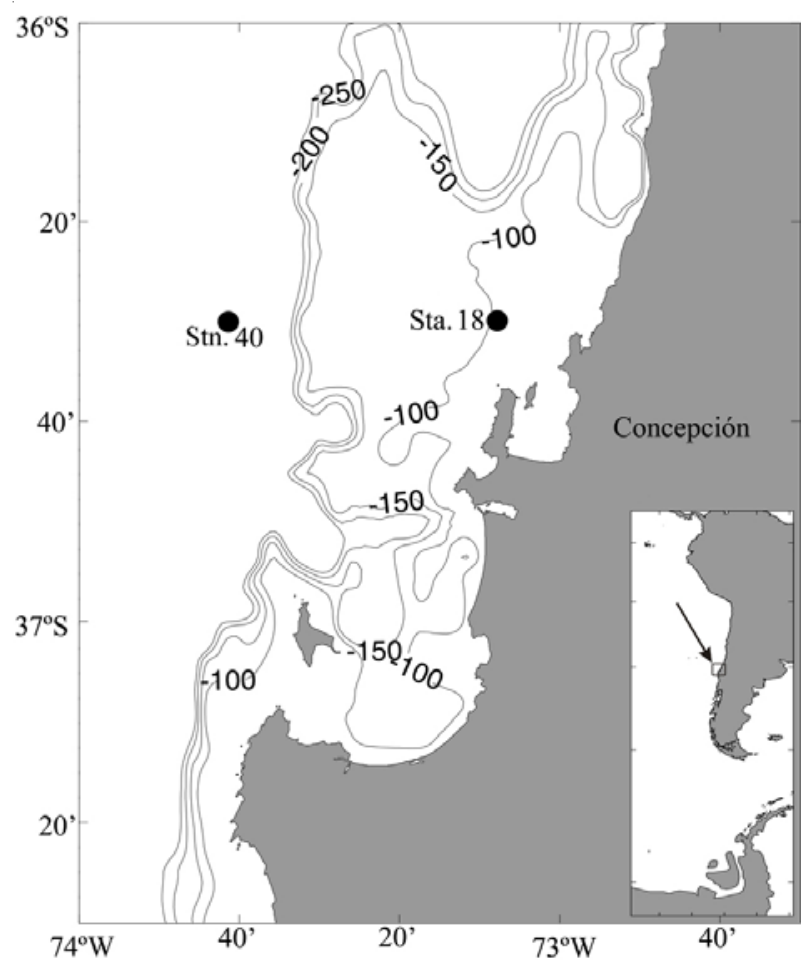

Figure 1

Location of the sampling stations in the Concepción area, Chile. Lines indicate the bathymetry

Localización de las estaciones de muestreo en el área de Concepción, Chile. Las líneas indican la batimetría

the R/V Kay-Kay. The sampling stations included one shelf station (Station 18: $33 \mathrm{~km}$ from the coast, $90 \mathrm{~m}$ depth, $36^{\circ} 29.94^{\prime} \mathrm{S}, 73^{\circ} 07.8^{\prime} \mathrm{W}$ ) and one at the shelf break (Station 40: $74 \mathrm{~km}$ from the coast, $750 \mathrm{~m}$ depth, $\left.36^{\circ} 30.040^{\prime} \mathrm{S}, 73^{\circ} 41.37^{\prime} \mathrm{W}\right)$. Sampling took place during the following dates at Stn 18: 12 December 2002, 15 January, 14 February, and 14 March 2003; and during 14 February 2003 at Stn 40. Discrete water samples were taken in the water column (4 to 9 depths strata) to characterise the vertical distribution of microorganisms, using Niskin bottles $(10 \mathrm{~L})$ and complemented with continuous CTD profiles (Seabird SBE25-02). Sample depths were chosen on the basis of the in vivo fluorescence (SEAPOINT in situ fluorometer) and oxygen profiles (SBE 23B oxygen sensor), both included in the same CTD casts. Discrete samples of chlorophyll$a$ (chl- $a$ ) and dissolved oxygen were also included to support the in situ sensor data. A linear regression analysis was run between dissolved oxygen samples and oxygen sensor data and the result was $\mathrm{r}^{2}=0.93$, in consequence oxygen sensor data was used for analysis. During March 2003 cruise the fluorescence sensor was not in operation therefore only chlorophyll- $a$ data is available for that sampling date.

Complementary, local wind data (at midday) were obtained for each of the sampling dates, and also from the previous 3 days in each case, in order to assess the occurrence of upwelling. Data were provided by the Bellavista meteorological station located at $4 \mathrm{~km}$ from the coast $\left(36^{\circ} 44^{\prime} \mathrm{S}, 73^{\circ} 05^{\prime} \mathrm{W}\right)$, with the exception of one set (14-Feb-03) which was obtained from the Carriel Sur meteorological station located at $9 \mathrm{~km}$ from the coast $\left(36^{\circ} 46^{\prime} \mathrm{S}, 73^{\circ} 03^{\prime} \mathrm{W}\right)$. Sea surface temperature (SST) and chlorophyll- $a$ spatial distributions covering the area of study for each of the sampling dates were derived from weekly satellite images obtained from the Ocean Color Web (http://oceancolor.gsfc.nasa.gov/). Each image was filtered by $3 \times 3$ moving average and draw with $1{ }^{\circ} \mathrm{C}$ contours in SST and $1 \mathrm{mg}$ chl- $a \mathrm{~m}^{-3}$ isoline.

\section{Abundance of virioplankton, bacterioplankton and nanoflagellates}

Water samples of $10 \mathrm{~mL}$ for VP, BP and $50 \mathrm{~mL}$ for nanoflagellates were collected in duplicate, immediately fixed with gluteraldehyde ( $2 \%$ final concentration) and stored in the dark at $4{ }^{\circ} \mathrm{C}$ until analysed. VP samples were processed during the first three days after collection by filtration onto a $25 \mathrm{~mm}, 0.02 \mu \mathrm{m}$ pore-size Anodisc membrane filters (Whatman) at $400 \mathrm{~mm} \mathrm{Hg}$ pressure. Filtration volumes ranged between 200 and $500 \mu \mathrm{L}$ for the shelf station (dilution from 1:4 to 1:1) and between 1 and $3 \mathrm{~mL}$ for the shelf-break station (dilution from 1:1 to $1: 0.3)$. Filtered samples were placed in the bottom of a pyrex Petri dish and stained with $80 \mu \mathrm{L}$ of the Yo-Pro-1 stock solution (1 mM Yo-Pro-1 in aqueous dimetyl sufoxide, Molecular Probes) that was diluted to a final concentration of $50 \mu \mathrm{M}$ in $0.02 \mu \mathrm{m}$ filtered Milli-Q water, according to the method of Hennes \& Suttle (1995) as modified by Xenopoulos \& Bird (1997). Following, samples were filtered at $400 \mathrm{~mm} \mathrm{Hg}$ pressure and rinsed three times by filtering with $500 \mu \mathrm{L}$ of pre-filtered $(0.02$ $\mu \mathrm{m})$ Milli-Q water. The samples were then irradiated for $3.5 \mathrm{~min}$ in a domestic microwave at the low-intermediate power level (level 3, TEKA, $700 \mathrm{~W}$ ). The heated Petri dish was left 10 min to cool off, after which the excess stain was removed by placing the filters on the filtering support and rinsing three times with aliquots of $800 \mu \mathrm{L}$ of pre-filtered $(0.02 \mu \mathrm{m})$ Milli-Q water. Filters were mounted between a glass slides and coverslips using 50\% spectrophotometric grade glycerol and stored at $-20^{\circ} \mathrm{C}$ until examined (about one week later). Blanks with prefiltered $(0.02 \mu \mathrm{m})$ Milli-Q water were made to assess 
potential contamination. BP samples were stained, for $10 \mathrm{~min}$, with DAPI $\left(10 \mu \mathrm{g} \mathrm{mL}^{-1}\right.$ final concentration), according to Porter \& Feig (1980). A volume of $2 \mathrm{~mL}$ (shelf station) or $3 \mathrm{~mL}$ (shelf-break station) was filtered onto $0.2 \mu \mathrm{m}$ pore-size black Millipore filters (vacuum pressure $<130 \mathrm{~mm} \mathrm{Hg}$ ), after which the samples were rinsed with $2 \mathrm{~mL}$ of pre-filtered $(0.2 \mu \mathrm{m})$ Milli-Q water. Thereafter, the filters were mounted on glass slides with a drop of filtered $(0.2 \mu \mathrm{m})$ Vaseline and a cover slip, and stored at $-20^{\circ} \mathrm{C}$ until processed (about one week later). Nanoflagellate samples were stained, during $15 \mathrm{~min}$, with DAPI (10 $\mu \mathrm{g} \mathrm{mL}^{-1}$ final concentration), following the same procedures as above. A volume of $20 \mathrm{~mL}$ was filtered onto $0.8 \mu \mathrm{m}$ pore size black Nucleopore filters and then mounted on glass slides and stored as above.

Particle identification and counting was performed with a Zeiss epifluorescence microscope (Model Axioskop 2 plus) under 1,600x magnification and equipped with a blue and UV light filter set. Cyanobacteria were distinguished from $\mathrm{BP}$ on the basis of the autofluorescent pigments (phycoerythrin or phycocyanin) in the former. ANF were recognised from HNF by the presence of chloroplasts which autofluoresce in the former ones. All samples were analysed in duplicate and for each 20, 10 and 50 fields were randomly selected to count VP, BP and nanoflagellates, respectively. The coefficient of variation of each sample analysed was less than $20 \%$ in all cases. In general, standard error (SE) was calculated by dividing samples' standard deviation (SD) by the square root of the number of samples analyzed (n), i.e. $\mathrm{SE}=S D / \sqrt{n}$

\section{Estimation of biomass of virioplankton, bacterioplankton and nanoflagellates}

VP biomass as carbon (C) was estimated assuming an average content of $0.2 \mathrm{fg} \mathrm{C} \mathrm{VLP}^{-1}$ (VLP stand for virus like particles) (Taylor et al. 2003). BP and nanoflagellate cell sizes were derived from photographic pictures of randomly selected fields. These photographs were processed with the OPTIMAS 6.1 software and size estimates were compared against a micro-scale of $10 \mu \mathrm{m}$ division (Carl Zeiss). The samples from $10 \mathrm{~m}$ depth were used for these measurements. In addition, samples from $80 \mathrm{~m}$ depth taken during one of the sampling dates were sized as to evaluate the adequacy of the $10 \mathrm{~m}$ depth stratum and no significant differences were found $(P>$ $0.05 \mathrm{n}=30$ ). Thirty bacteria from the $10 \mathrm{~m}$ depth samples, from all the sampling dates and stations, were selected at random for estimations of the average cell length (1) and diameter (d) in order to calculate cell volume according to Watson et al. (1977):

$$
\text { BIOVOLB }\left(\mu m^{3}\right)=\left(d^{2} \times \frac{\pi}{4}\right) \times(l-d)+\left(\pi \times \frac{d^{3}}{6}\right)(1)
$$

HNF and ANF length (l) and width (w) were measured in up to 10 cells, from the samples also taken at $10 \mathrm{~m}$ depth, during all the sampling dates and stations, and the volume was calculated according to Chrzanowski \& Simek (1990):

$$
\operatorname{BIOVNF}\left(\mu m^{3}\right)=\left[\left(\frac{\pi}{6}\right) \times l\right] \times w^{2}(2)
$$

To convert bacterial biovolume $\left(\mu \mathrm{m}^{3}\right)$ to biomass in carbon units $(\mathrm{C} ; \mathrm{fg})$, the following formula was used (Simon \& Azam 1989):

$$
\mathrm{C}=90.06 \mathrm{~V}^{0.59}
$$

Nanoflagellate biovolume was converted to biomass in carbon units $(\mathrm{C} ; \mathrm{fg})$ using a conversion factor of 220 fg $\mathrm{C} \mu \mathrm{m}^{-3}$ (Børsheim \& Bratbak 1987).

In addition, integrated abundances and biomasses of the microbial components were calculated for all the sampling dates and for both stations, including the maximum depth at the shallower station $(0-80 \mathrm{~m}$ at Stn 18 vs. $0-75 \mathrm{~m}$ at $\operatorname{Stn} 40$ ). In comparing the carbon biomass of the microbial components (except VP) with the total autotrophic biomass in the water column, a C:chl- $a$ ratio of 30 (Strickland 1960, Riemann et al. 1989) was applied to the chl- $a$ data.

Non-parametric statistics was applied to analyze the data because all the variables examined were not normally distributed, after checking by the Shapiro-Wilk W test for normal distribution. The potential intensity of associations between the abundances of the different components was assessed by Spearman rank correlation (r), at the 0.05 level of significance, combining the data for all cruises and depths. Since regression statistics are known to be robust with respect to the normality distribution assumptions (Zar 1999), relationship between microbial assemblages (dependent variable) and oceanographic variables (i.e. temperature, salinity and dissolved oxygen as independent variables) was examined by simple linear regressions. Significant differences between upwelling and non-upwelling sampling dates were assessed by Mann-Whitney U-test. All tests and statistical analyses were conducted using STATISTICA 7.0 software package. 


\section{Results}

\section{Oceanographic conditions during the upwelling season 2002-2003}

Before all samplings dates, the predominant direction of the local winds was S-SW (Fig. 2A), i.e. the Ekman transport was positive representing transport offshore; the highest values of the sampling period were registered during 15-Jan-03 (Fig. 2B). The distribution of the SST revealed a colder band (less than $\sim 14^{\circ} \mathrm{C}$ ) for Stn 18 and 40 during 14-Feb-03 (Fig. 3C) and for the rest of the sampling dates Stn 18 was under less than $14.5^{\circ} \mathrm{C}$ (Fig. $3 \mathrm{~A}, \mathrm{~B}$ and $\mathrm{D})$. Color images indicate that during all sampling dates Stn 18 presented values of chl- $a$ higher than $7 \mathrm{mg}$ chl- $a \mathrm{~m}^{-3}$, the same happened for Stn 40 during 14-Feb-03 (Fig. 3G). The surface temperature at Stn 18 (Fig. 4A-C and E) was relatively homogeneous between the sampling dates $\left(13.0-13.3^{\circ} \mathrm{C}\right)$. At Stn 40 (Fig. 4D), surface temperature was slightly lower $\left(12.6^{\circ} \mathrm{C}\right)$ than the one observed at $\operatorname{Stn} 18\left(13.2^{\circ} \mathrm{C}\right.$; Fig. $\left.4 \mathrm{C}\right)$ during the same day. Temperature vertical profiles showed a relatively shallow mixed layer $(<20 \mathrm{~m}$ depth) at Stn 18 and a not marked mixed layer at Stn 40 . Values approached $11^{\circ} \mathrm{C}$ in the waters below the mixed layer at Stn 18 during all sampling dates and within the surface $100 \mathrm{~m}$ layer at Stn 40 (Fig. 4D). A halocline was also evident at both stations, its base usually coinciding with the base of the thermocline (Fig. 4A-E). Salinity values in the water column varied in a narrow range (34.48-34.73 psu) during the sampling dates at Stn 18. Similarly, values at Stn 40 were comparatively lower than at Stn 18 , with values higher than 34.5 psu being found below the $80 \mathrm{~m}$ depth (Fig. 4D). The higher salinity values indicated the presence of Equatorial Subsurface Waters (ESSW) at Stn 18 during all the samplings (Silva \& Konow 1975), whereas the lower salinities in the upper layers of Stn 40 indicated a greater influence of the Subantarctic Surface Waters (SASW; Silva \& Konow 1975, Sobarzo 1994).

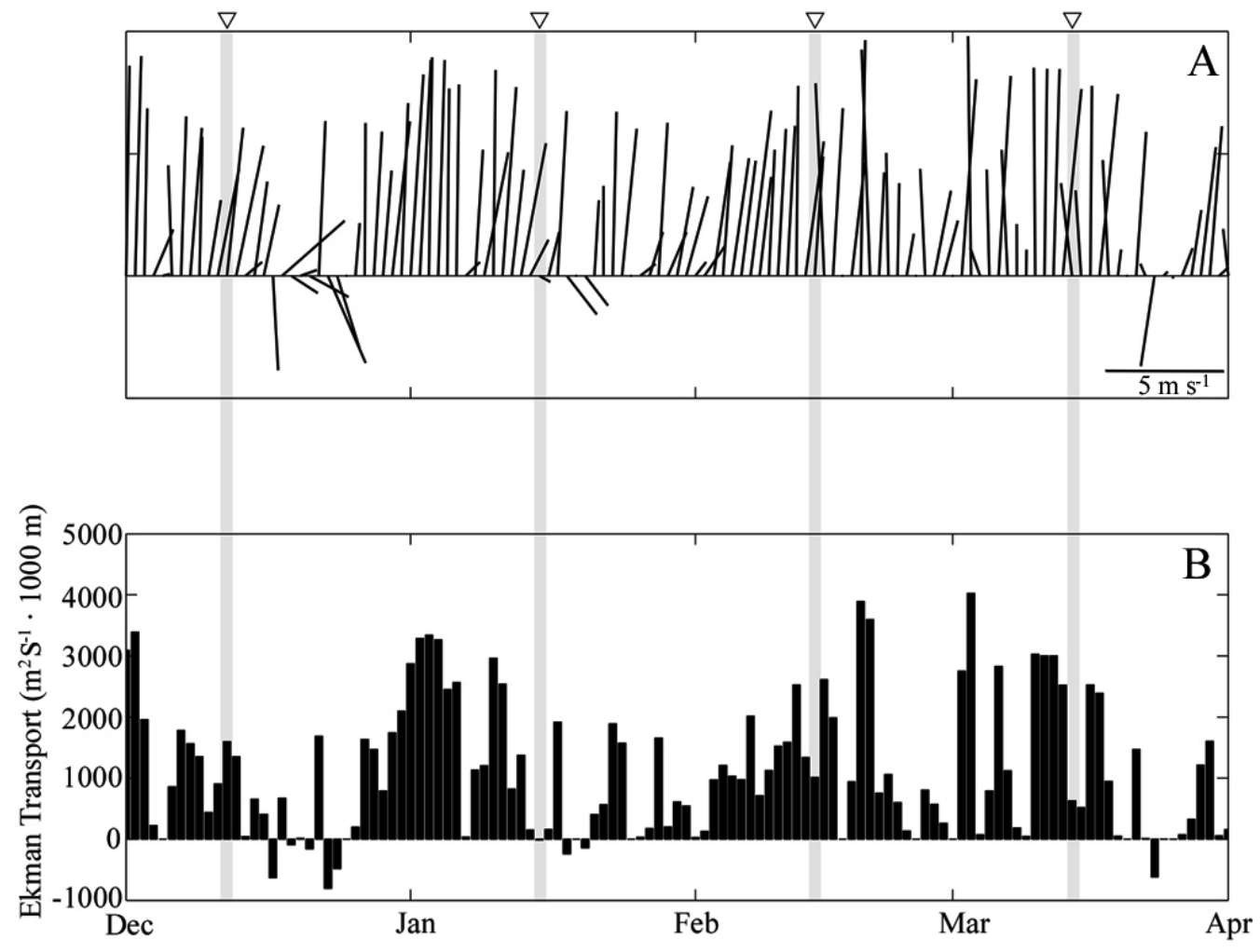

Figure 2

Wind and Ekman transport: (A) diagram showing directions and velocities ( $\mathrm{m} \mathrm{s}^{-1}$ ) of wind and (B) magnitude of Ekman transport $\left(\mathrm{m}^{2} \mathrm{~s}^{-1} 1000 \mathrm{~m}\right)$. Positive Ekman transport indicates surface offshore transport

Viento y transporte de Ekman (A) diagrama que indica las direcciones y velocidades ( $\mathrm{m} \mathrm{s}^{-1}$ ) del viento y (B) la magnitud del transporte de Ekman $\left(\mathrm{m}^{2} \mathrm{~s}^{-1} 1000 \mathrm{~m}\right)$. Transporte positivo de Ekman indica transporte superficial hacia fuera de la costa 

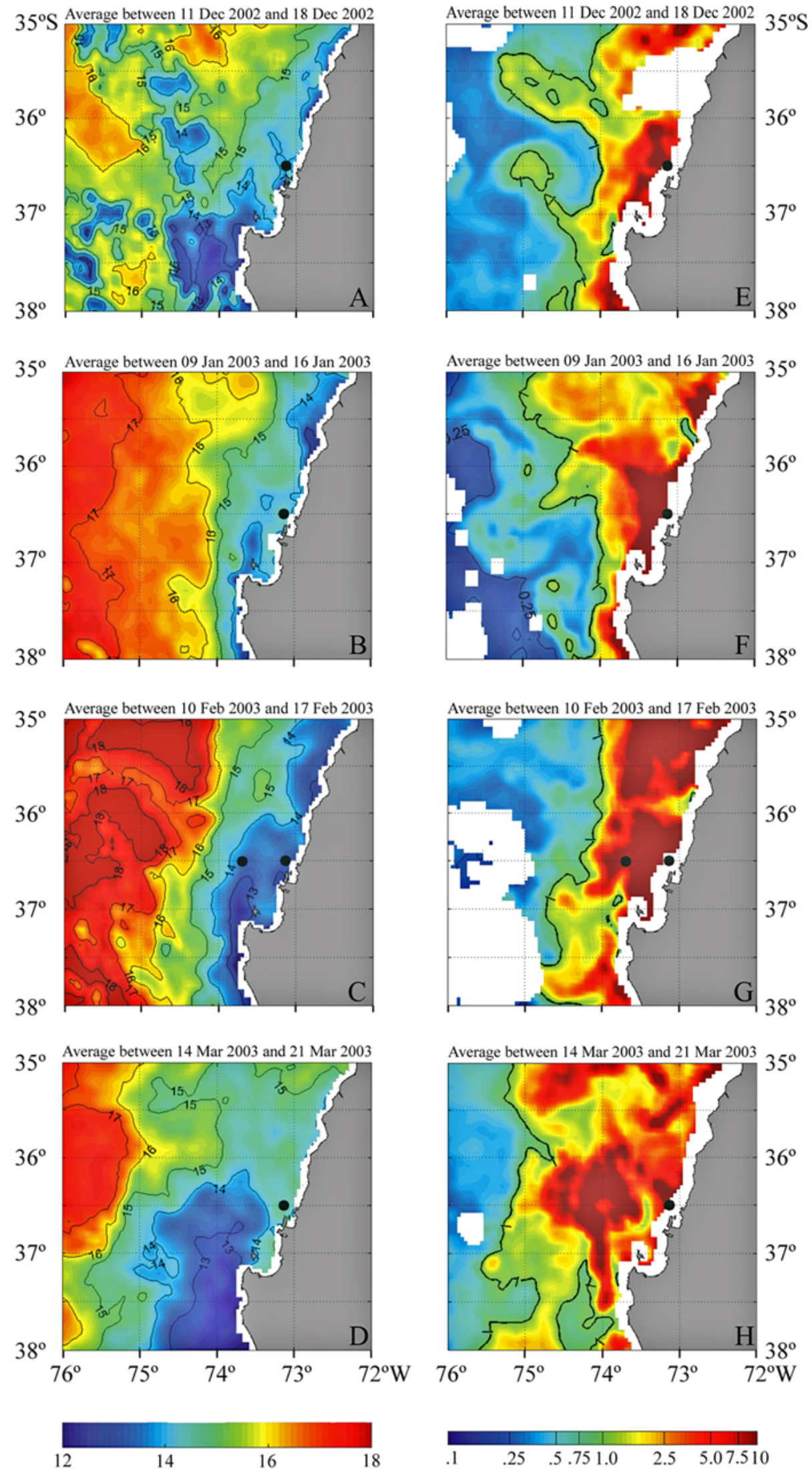


\section{Figure 3}

Satellite images of one week average seawater surface temperature in the area of study off Concepción, representing upwelling (A, 14-Feb-2003; B, 14-Mar-2003) and non-upwelling influenced waters (C, 12-Dec-2002; D, 15-Jan-2003) and colour images of chlorophyll- $a\left(\mathrm{mg} \mathrm{chl}-a^{-3}\right)$ for the same periods (E to $\left.\mathrm{H}\right)$. Stn 18 and Stn 40 for 14-Feb-2003 are represented accordingly by a black circle on each image

Imágenes de satélite, promedio de una semana de la temperatura superficial del mar en el área de estudio de Concepción, representando surgencia (A, 14-Feb-2003; B, 14-Mar-2003) y aguas no influenciadas por surgencia (C, 12-Dic-2002; $\mathrm{D}, 15$-Ene-2003) e imágenes de color de clorofila-a ( $\left.\mathrm{mg} \mathrm{chl-} a \mathrm{~m}^{-3}\right)$ para el mismo periodo $(\mathrm{E}$ a $\mathrm{H})$. Est $18 \mathrm{y}$ Est 40 para 14-Feb-2003 son representadas por un circulo negro en cada imagen

A well defined oxycline, at a relatively shallow level (20$35 \mathrm{~m}$ depth), occurred during all the samplings at Stn 18, its base usually coinciding with those of the thermocline and the halocline (Fig. 4A-C and E). Surface waters were well oxygenated $\left(>267.96 \mathrm{mmol} \mathrm{O}_{2} \mathrm{~m}^{-3}\right)$ with the exception of the sampling on 14-Mar-03, when values of $\sim 178.64 \mathrm{mmol} \mathrm{O}_{2} \mathrm{~m}^{-3}$ (both, CTD sensor readings and discrete samples) were found in the top $15 \mathrm{~m}$ (Fig. 4E). Values lower than $89.32 \mathrm{mmol} \mathrm{O}_{2} \mathrm{~m}^{-3}$ below the oxycline signalised the presence of suboxic conditions, characteristics of the region and associated with the oxygen minimum zone (OMZ) and the core of the ESSW (Silva \& Konow 1975, Sobarzo 1994). At Stn 40 (Fig. 4D), oxygen concentration decreased gradually with depth, achieving OMZ values below $50 \mathrm{~m}$ depth.

The fluorescence profiles, and the chl- $a$ discrete values indicated the occurrence of surface and subsurface maxima at Stn 18 , usually within the mixed layer $(<20 \mathrm{~m}$ depth; Fig. 4A-C). Fluorescence data from 14-Mar-03 were not available, but discrete values indicated a maximum at $\sim 10 \mathrm{~m}$ depth (Fig. 4E), although this maximum was very low $\left(<1 \mathrm{mg} \mathrm{chl}-a \mathrm{~m}^{-3}\right)$ in comparison to the other sampling dates $\left(>8 \mathrm{mg}\right.$ chl- $\left.a \mathrm{~m}^{-3}\right)$. Whereas very high values ( $>18 \mathrm{mg}$ chl- $\left.a \mathrm{~m}^{-3}\right)$ were found during 15-Jan-03 and 14-Feb-03 (Fig. 4B and C). At Stn 40, values were also very high $\left(>10 \mathrm{mg}\right.$ chl- $\left.a \mathrm{~m}^{-3}\right)$ and occurred at the surface ( $<10 \mathrm{~m}$ depth) (Fig. 4D).

\section{VP, BP, HNF and ANF abundances and vertical distribution}

VP abundance was evaluated during three sampling periods at Stn 18 (no data for 14-Mar-03). The values varied widely between sampling dates (3) and depths (0$80 \mathrm{~m}$ depth), ranging between 0.045 and $13.9 \times 10^{7} \mathrm{VLP}$ $\mathrm{mL}^{-1}$ (Fig. 5A), with a mean of $1.6( \pm \mathrm{SE} 0.7) \times 10^{7} \mathrm{VLP}$ $\mathrm{mL}^{-1}$. The maximum values occurred within the mixed layer ( $<20 \mathrm{~m}$ depth) and gradually decreased with depth.

The overall range of $\mathrm{BP}$ abundance values at Stn 18 (Fig. 5B) was 0.5 to $5.6 \times 10^{6}$ cells $\mathrm{mL}^{-1}$, with a mean of $2.0( \pm \mathrm{SE} 0.2) \times 10^{6}$ cells $\mathrm{mL}^{-1}$. Subsurface maxima within the mixed layer occurred during two dates (12-Dec-02 and 14-Feb-03) while the two others (15-Jan-03 and 14Mar-03) displayed relatively constant values throughout the water column. Cyanobacteria (data not shown) appeared in the top $40 \mathrm{~m}$ layer but represented less than $1.2 \%$ of the total BP abundance (average: 3.2 ( \pm SE 0.3 ) x $10^{3}$ cells $\mathrm{mL}^{-1}$, range: $2.0-4.9 \times 10^{3}$ cells $\left.\mathrm{mL}^{-1}\right)$.

The abundances of HNF (Fig. 5C) and ANF (Fig. 5D) in the water column at Stn 18, during the sampling dates (4), were in the range of 0.02-0.4 x $10^{3}$ and 0.01-0.6 $\mathrm{x}$ $10^{3}$ cells $\mathrm{mL}^{-1}$, respectively, with means of 0.1 ( $\pm \mathrm{SE} 0.02$ ) $\mathrm{x} 10^{3}$ cells $\mathrm{mL}^{-1}$ in both cases. Vertical profiles indicated a more or less uniform distribution in the water column (0-80 $\mathrm{m}$ depth) but a subsurface maximum within the mixed layer was present on 12-Dec-02 for HNF and ANF. A weak subsurface maximum was presented for HNF on 15-Mar-03 and for ANF on 14-Feb-03 (Fig. 5C and D) In general terms, the abundances of the microbial components were variable in the mixed layer ( top $20 \mathrm{~m}$ depth) during the different samplings at Stn 18 and during sampling dates 12 -Dec-02 and 14-Feb-03 were presented the highest abundances in the mixed layer.

At the shelf break station (Stn 40), sampled only during 14-Feb-03, VP abundance mean was 2.2 ( $\pm \mathrm{SE}$ 0.7 ) $\times 10^{7}$ VLP $\mathrm{mL}^{-1}$ (range: 0.02 to $5.4 \times 10^{7} \mathrm{VLP}$ $\mathrm{mL}^{-1}$ ). Two maxima of VP abundance were present, one at the surface and one lower below the mixed layer (Fig. 6A). The range of BP abundance was from 0.96 to 3.35 x $10^{6}$ cells $\mathrm{mL}^{-1}$, with a mean of $1.9( \pm \mathrm{SE} 0.26) \times 10^{6}$ cells $\mathrm{mL}^{-1}$; a maximum appeared at the surface but values close to the average $\left(>1.6 \times 10^{6}\right.$ cells $\left.\mathrm{mL}^{-1}\right)$ were present in the top $50 \mathrm{~m}$, after which values decreased with depth (Fig. 6B). Cyanobacteria (data not shown) were present in the top $75 \mathrm{~m}$ and represented a small percentage of total BP abundance $(<0.4 \%)$, with a mean value of 4.3 $( \pm \mathrm{SE} 0.56) \times 10^{3}$ cells $\mathrm{mL}^{-1}$. The HNF abundance mean was 0.1 ( $\pm \mathrm{SE} 0.01) \times 10^{3}$ cells $\mathrm{mL}^{-1}$ (range: 0.01 to 0.12 X $10^{3}$ cells $\mathrm{mL}^{-1}$ ) and their distribution was relatively uniform in the water column (Fig. 6C). ANF abundances presented maximum values within the mixed layer (Fig. 6D) with a ranged between 0.02 and $0.5 \times 10^{3}$ cells $\mathrm{mL}^{-1}$, (mean: $0.3( \pm \mathrm{SE} 0.1) \times 10^{3}$ cells $\left.\mathrm{mL}^{-1}\right)$. 


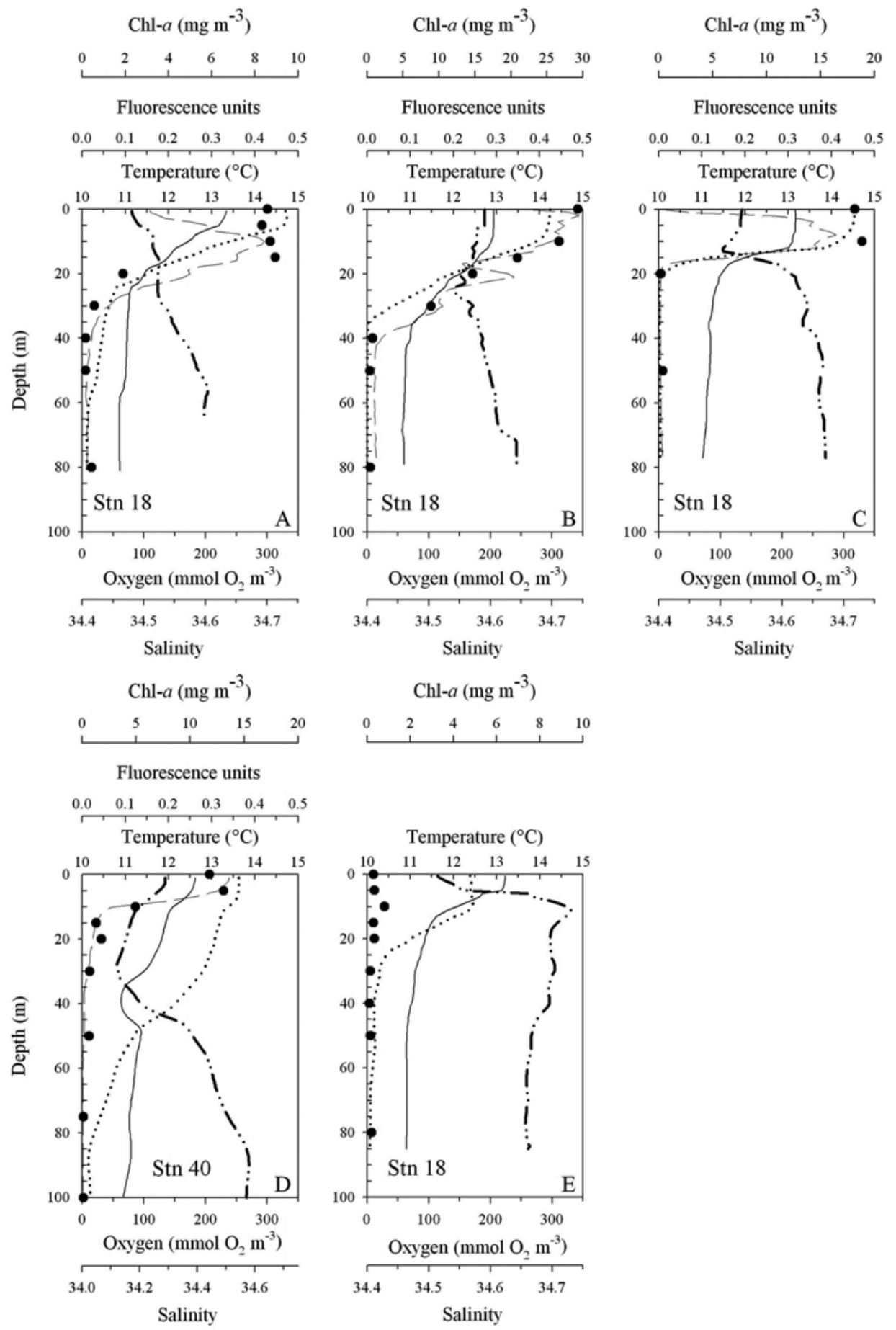

Figure 4

Vertical profiles of temperature (straight line), salinity (dash dot-dot line), oxygen (dotted line), fluorescence units (long dash line) and chl-a (filled circle) at Stn 18 during (A) 12-Dec-2002, (B) 15-Jan-2003, (C) 14-Feb-2003, and (E) 14-Mar-2003 and at Stn 40 during (D) 14-Feb-2003 in the area off Concepción

Perfiles verticales de temperatura (línea recta), salinidad (línea guión punto-punto), oxígeno (línea punteada), unidades de fluorescencia (línea guión largo) y chl-a (círculo relleno) en Est 18 durante (A) 12-Dic-2002, (B) 15-Ene-2003,

(C) 14-Feb-2003, y (E) 14-Mar-2003 y en Est 40 durante (D) 14-Feb-2003 en el área de Concepción 


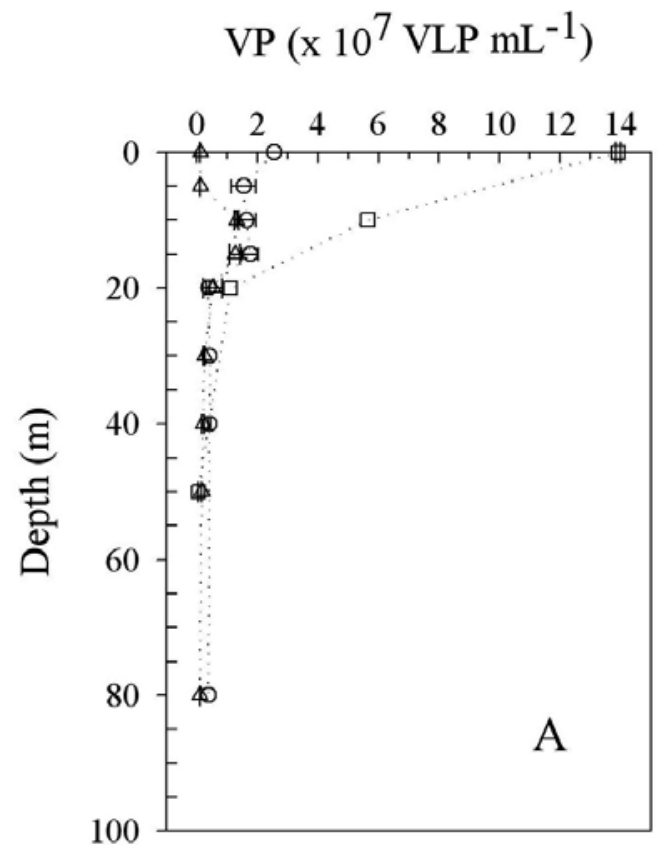

$\mathrm{BP}\left(\times 10^{6}\right.$ cells $\left.\mathrm{mL}^{-1}\right)$
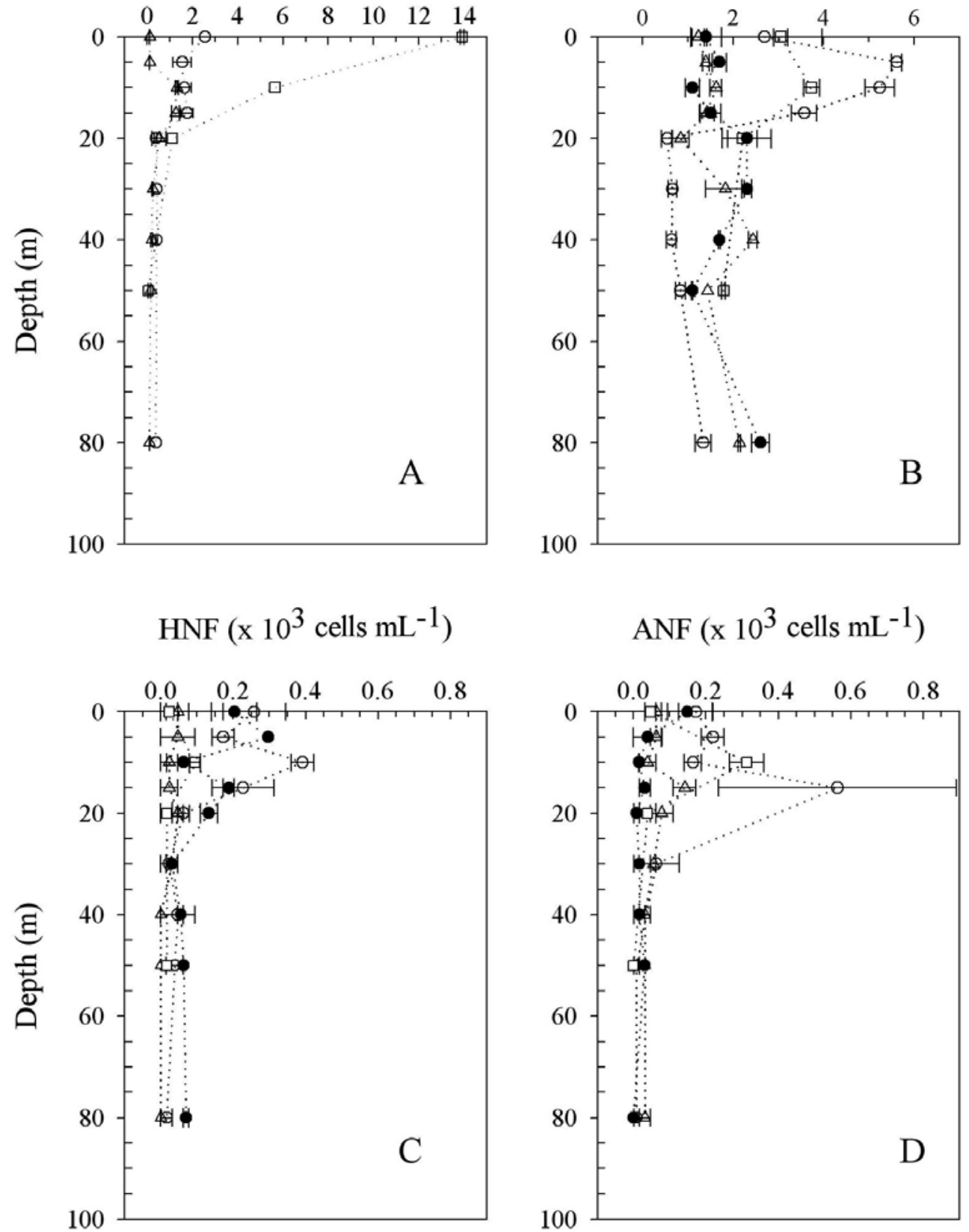

$\operatorname{ANF}\left(\times 10^{3}\right.$ cells $\left.\mathrm{mL}^{-1}\right)$

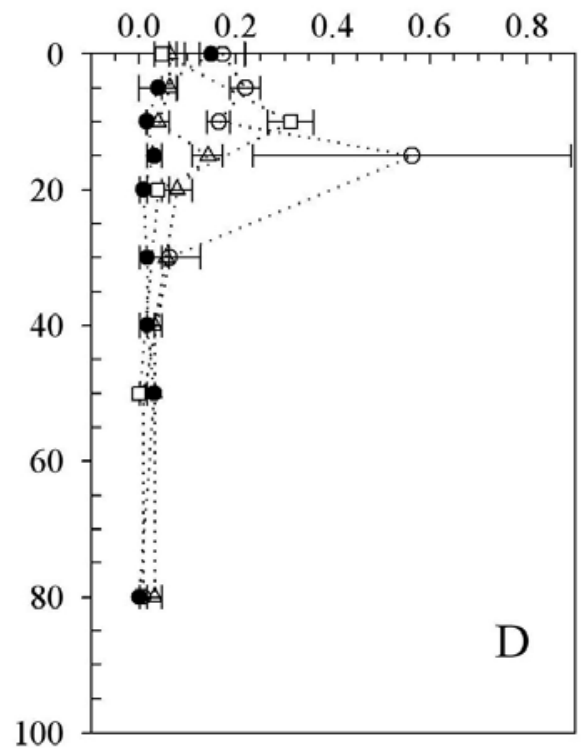

Figure 5

Vertical distribution of VP (A), BP (B), HNF (C) and ANF (D) during the upwelling season (December 2002 - March 2003) at the shelf (Stn 18) in the area off Concepción. Each symbol represents different sampling dates (o = 12-Dec-02, $\Delta=15-J a n-03, \square=14-F e b-03, \bullet=14-M a r-03)$. Bars indicate standard error

Distribución vertical de VP (A), BP (B), HNF (C) y ANF (D) durante la estación de surgencia (diciembre 2002 - marzo 2003) en la plataforma (Est 18) en el área de Concepción. Cada símbolo representa diferentes días de muestreo (o = 12-Dic-02, $\Delta=15$-Ene-03, $\square=14$-Feb-03, $\bullet=14$-Mar-03). Barras indican el error estándar 

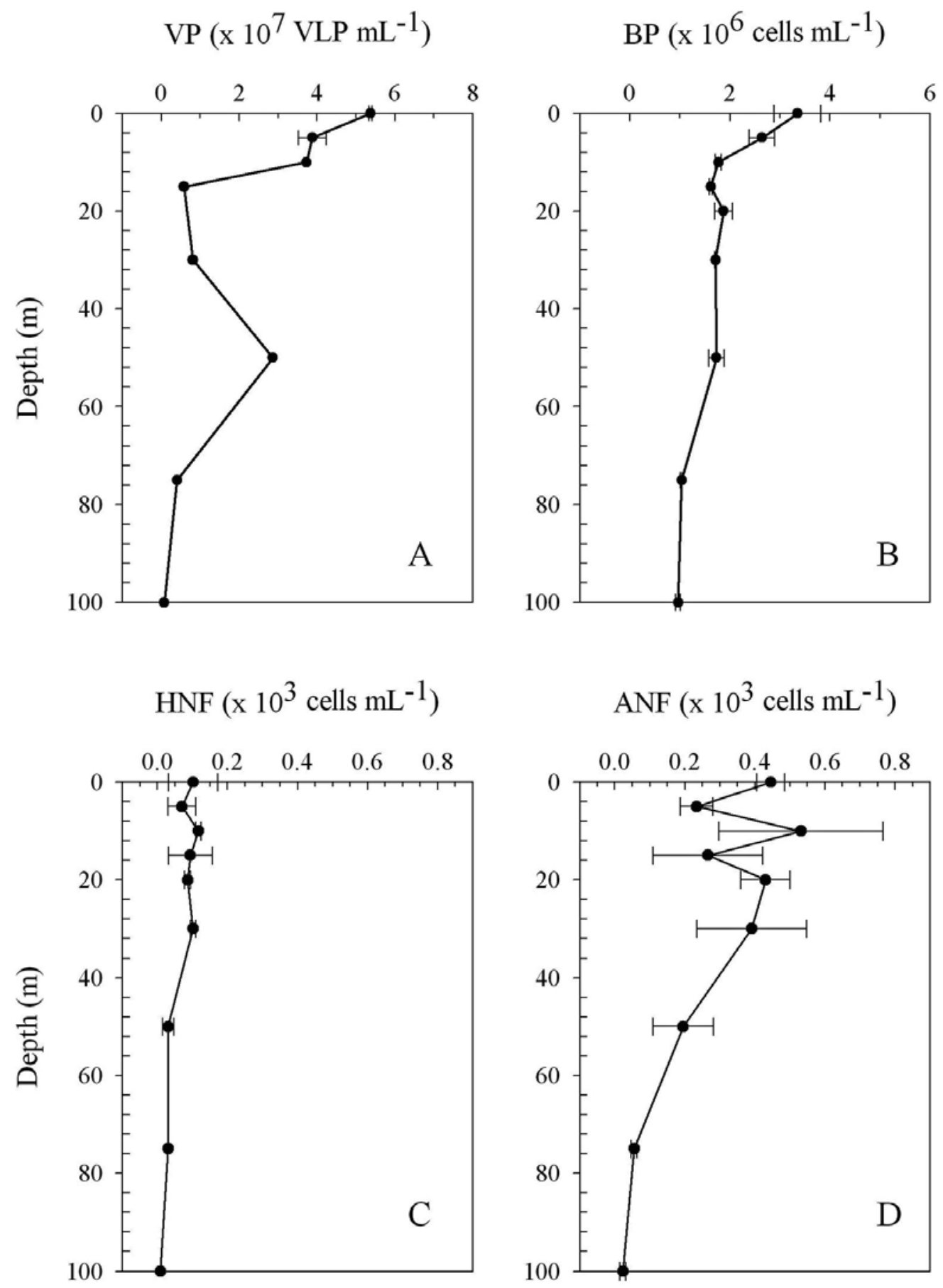

Figure 6

Vertical distribution of VP (A), BP (B), HNF (C) and ANF (D) at the shelf break (Stn 40, 14-Feb-03) in the area off Concepción. Bars indicate standard error

Distribución vertical de VP (A), BP (B), HNF (C) y ANF (D) en el quiebre de la plataforma (Est 40, 14-Feb-03) en el área de Concepción. Barras indican el error estándar 


\section{Microbial abundances in relation to oceanographic conditions and between groups}

The variability in the abundances of VP, BP, HNF and ANF during all the samplings was not explained at all by chl- $a$ abundance which relationship presented values of $\mathrm{r}^{2}<0.07, P>0.1$, data was not plotted. The variables temperature, salinity and dissolved oxygen poorly explained (coefficient of determination $<27 \%$ for linear regressions) the total variation of $\mathrm{VP}, \mathrm{BP}, \mathrm{HNF}$ and $\mathrm{ANF}$ abundances, with the exception of salinity for ANF with $r^{2}=0.63 ; P<0.05$ (Fig. 7). Only in the case of dissolved oxygen, all coefficient of determination were significant with $P<0.05$, although this variably explained a low percentage $(25 \%)$ of the abundance variability of the microbial components (Fig. 7). Only the significant relationships were plotted on Fig. 7.
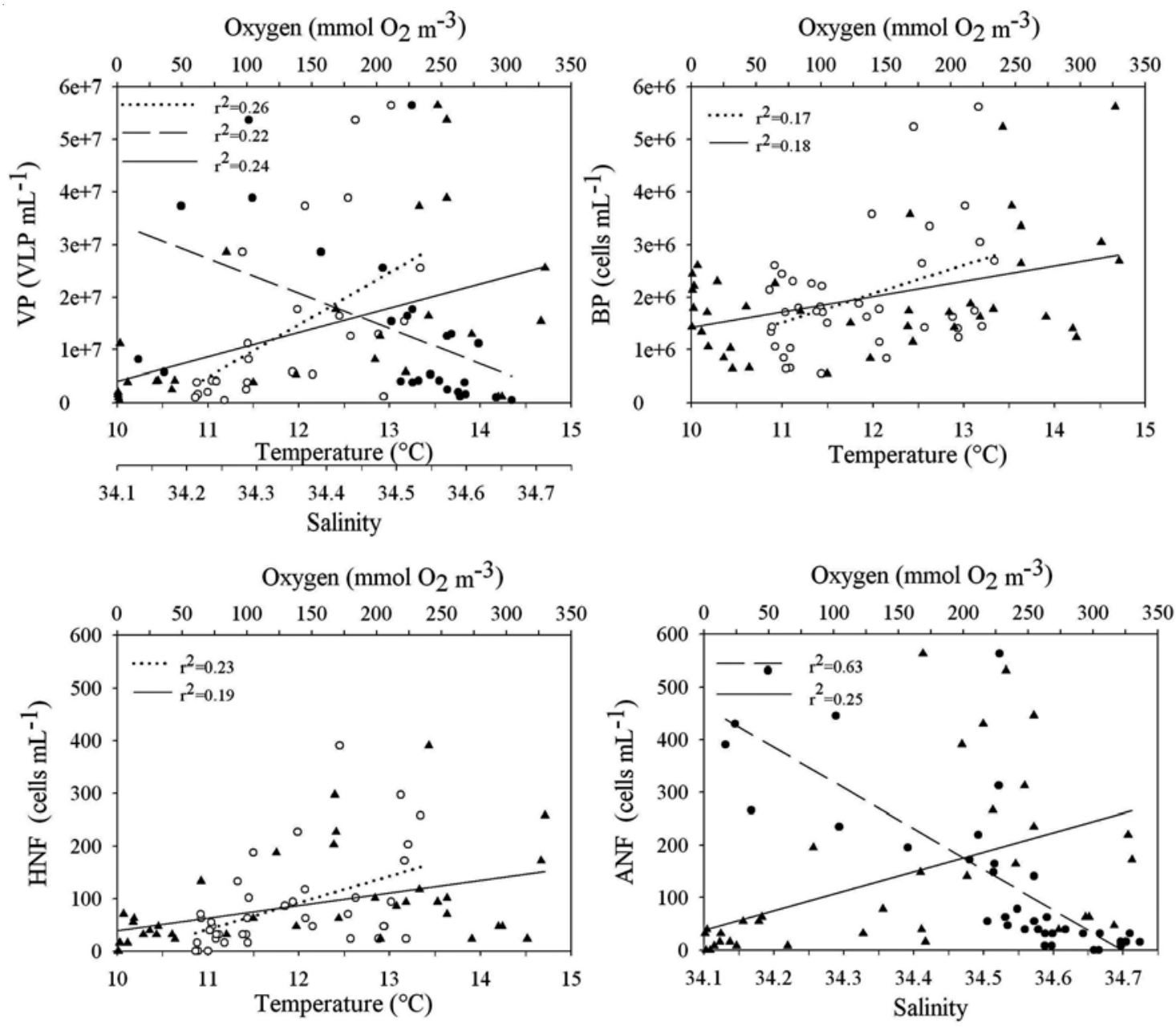

Figure 7

Relationship between VP, BP, HNF, ANF and temperature (o), salinity (•) and dissolved oxygen ( $\triangle$ ) grouping the data for the four sampling dates and both stations conducted in the area off Concepción. In addition, the regression

linear curves and $\mathbf{r}^{2}$ are shown only for the relationship that showed significant $\mathrm{p}$ values (i.e. $\left.P<0.05\right)$.

Temperature (dotted line), salinity (long dash line) and oxygen (solid line)

Relación entre VP, BP, HNF, ANF y temperatura (o), salinidad (•) y oxígeno disuelto ( $\mathbf{\Delta}$ ) agrupando los datos de ambas estaciones y los cuatro muestreos realizados en el área de Concepción. Además se muestran las curvas de regresión lineal y $\mathrm{r}^{2}$ para cada una de las relaciones que mostraron valores significativos de $\mathrm{p}$ (i.e. $P<0,05$ ).

Temperatura (línea punteada), salinidad (línea guión largo) y oxígeno (línea recta) 


\section{Table 1}

Integrated abundance and biomass of microbial assemblages at Stn 18 and 40 off Concepción. Depth of integration: $80 \mathrm{~m}$ at Stn 18 and $75 \mathrm{~m}$ at Stn 40,* $50 \mathrm{~m}$ integration depth (unfavourable weather conditions aborted sampling deeper). OC $=$ oceanographic conditions, $\mathrm{NUC}=$ non-upwelling conditions and $\mathrm{UC}=$ upwelling conditions, $\mathrm{NA}=$ data not available

Abundancia y biomasa integrada de ensambles microbianos en la Est 18 y 40 en Concepción. Profundidad de integración: $80 \mathrm{~m}$ en Est 18 y $75 \mathrm{~m}$ en la Est 40, * $=50 \mathrm{~m}$ profundidad de integración (condiciones de tiempo desfavorables, el muestreo a mayor profundidad fue abortado). $\mathrm{OC}=$ condiciones oceanográficas, $\mathrm{NUC}=$ condiciones de no surgencia y $\mathrm{UC}=$ condiciones de surgencia, $\mathrm{NA}=$ datos no disponibles

\begin{tabular}{|c|c|c|c|c|c|c|c|c|c|c|c|}
\hline \multirow[b]{2}{*}{ Location } & \multirow[b]{2}{*}{ Date } & \multirow[b]{2}{*}{$\mathrm{OC}$} & \multicolumn{4}{|c|}{ Integrated abundance $\left(10^{12}\right.$ cells $\left.\mathrm{m}^{-2}\right)$} & \multicolumn{4}{|c|}{ Integrated biomass $\left(10^{6} \mu \mathrm{gC} \mathrm{\textrm {m } ^ { - 2 }}\right)$} & \multirow[b]{2}{*}{ PH } \\
\hline & & & VP* & $\mathrm{BP}$ & HNF & ANF & VP & $\mathrm{BP}$ & HNF & ANF & \\
\hline Stn 18 & 12-Dec-02 & NUC & 564 & 133 & 0.007 & 0.009 & 0.11 & 3.1 & 0.01 & 0.014 & 5.5 \\
\hline Stn 18 & 15-Jan-03 & NUC & 267 & 135 & 0.001 & 0.004 & 0.05 & 3.1 & 0.004 & 0.103 & 18.6 \\
\hline Stn 18 & $* 14-\mathrm{Feb}-03$ & $\mathrm{UC}$ & 1,491 & 124 & 0.002 & 0.004 & 0.30 & 2.1 & 0.0004 & 0.027 & 8.7 \\
\hline Stn 40 & 14-Feb-03 & $\mathrm{UC}$ & 1,408 & 130 & 0.005 & 0.02 & 0.28 & 2.2 & 0.028 & 0.183 & 4.9 \\
\hline Stn 18 & $14-03-03$ & $\mathrm{UC}$ & NA & 143 & 0.007 & 0.002 & NA & 2.7 & 0.008 & 0.031 & 0.6 \\
\hline
\end{tabular}

VP integrated abundances (267 to $1,491 \times 10^{12}$ VLP $\mathrm{m}^{-2}$ ) were the highest values reported for the microbial community (Table 1). At the shelf station VP integrated abundances varied between the three sampling dates, being approximately 3 to 6 times higher during one of the active upwelling samplings (14-Feb-03) (no data available for the other upwelling sampling, 14-Mar-03) (Table 1). VP integrated abundances values were slightly higher (1.5 times) at Stn $18\left(1,491 \times 10^{12} \mathrm{VLP} \mathrm{m}^{-2}\right)$ in comparison to Stn $40\left(1,001 \times 10^{12} \mathrm{VLP} \mathrm{m}^{-2}\right.$, integrated up to $50 \mathrm{~m}$ ), sampling below $50 \mathrm{~m}$ was cut out at Stn 18 due to bad weather (14-Feb-03). VP integrated biomass was 1-3 times lower than BP integrated biomass, but 1-2 times higher than ANF and HNF integrated biomass (Table 1). BP integrated abundances and biomasses (Table 1) at the shelf station were similar between the sampling dates in the water column, being unrelated to the upwelling condition; the two stations for the same date displayed similar BP integrated abundances and biomasses.

HNF and ANF integrated abundances and biomasses (Table 1) showed differences between sampling dates and between stations. HNF abundances and biomasses were slightly higher at Stn 18 during the sampling dates, 12Dec-2002 and 14-Mar-2003, with the highest values at Stn 40 (Table 1), although they were not related to the upwelling conditions. Differences in HNF integrated abundances and biomasses between the two stations were also evident for the same sampling date, being higher at the Stn 40 (2-3 times in abundance but almost one order of magnitude for biomass). Variability in ANF integrated abundance at Stn 18 was also unrelated to upwelling condition, presenting the highest values during one of the non-upwelling conditions (12-Dec-2002), and ANF integrated biomass was also the highest during one of the non-upwelling samplings (15-Jan-2003). At Stn 40, ANF integrated abundances and biomasses were almost twice higher than at Stn 18 for the same sampling date.

Phytoplankton (PH) integrated biomass was higher during all sampling dates than ANF integrated biomass, the highest value was reported for a non-upwelling sampling date, 15-Jan-03, and the lowest for 14-Mar-2003 an upwelling sampling date, not showing any relationship with upwelling conditions (Table 1). Phytoplankton biomass presented the highest values within the mixed layer for all sampling dates and exceeded BP biomass within the mixed layer at both stations, except at Stn 18 on 14-Mar-2003 when BP biomass was higher in the whole of the water column (Table 2). The $\mathrm{BP} / \mathrm{PH}$ ratio (Table 2) ranged from 0.03 (15-Jan-2003) to 10.3 in deeper waters ( $>30 \mathrm{~m}$ depth) during upwelling conditions (14-Mar-2003). ANF (size $<6 \mu \mathrm{m})$ were a small 
Table 2

Biomass data at Stn 18 and 40 off Concepción. Comparison of bacterial biomass and chlorophyll-based phytoplankton (PH) biomass (BP/PH), percentage of ANF from total phytoplankton (ANFP) and comparison between VP and BP abundances (VP/BP ratio). * $=50 \mathrm{~m}$ (unfavourable weather conditions aborted sampling deeper). NUC = non-upwelling conditions and UC = upwelling conditions, MLD = mixed layer depth $(\mathrm{m})$, NA = data not available

Datos de biomasa en la Est 18 y 40 en Concepción. Comparación de la biomasa bacteriana y fitoplanctónica (PH) basada en clorofila (BP/PH), porcentaje de ANF (ANFP) del fitoplancton total y comparación entre la abundancia de VP y BP (razón VP/BP). ${ }^{*}=50 \mathrm{~m}$ (condiciones de tiempo desfavorables, el muestreo a mayor profundidad fue abortado).

$\mathrm{NUC}=$ condiciones de no surgencia y $\mathrm{UC}=$ condiciones de surgencia, MLD = profundidad de la capa de mezcla $(\mathrm{m}), \mathrm{NA}=$ datos no disponibles

\begin{tabular}{|c|c|c|c|c|c|c|c|c|c|}
\hline Location & Station & Date & $\begin{array}{l}\text { Depth } \\
\text { (m) }\end{array}$ & $\begin{array}{c}\text { PH } \\
\left(\mu g C L^{-1}\right)\end{array}$ & $\begin{array}{c}\mathrm{BP} \\
\left(\mu \mathrm{gC} \mathrm{L} \mathrm{L}^{-1}\right)\end{array}$ & $\mathrm{BP} / \mathrm{PH}$ & $\begin{array}{c}\text { ANF } \\
\left(\mu \mathrm{gC} \mathrm{L}^{-1}\right)\end{array}$ & ANFP & $\mathrm{VP} / \mathrm{BP}$ \\
\hline \multirow[t]{10}{*}{$36^{\circ} 29.94^{\prime} \mathrm{S}, 73^{\circ} 07.8^{\prime} \mathrm{W}$, NUC } & Stn 18 & 12-Dec-02 & & & & & & & \\
\hline & MLD : & 24 & 0 & 257.4 & 62.3 & 0.2 & 0.26 & 0.10 & 10 \\
\hline & & & 5 & 249.9 & 130.0 & 0.5 & 0.34 & 0.13 & 3 \\
\hline & & & 10 & 261.3 & 121.2 & 0.5 & 0.25 & 0.10 & 3 \\
\hline & & & 15 & 268.2 & 82.7 & 0.3 & 0.87 & 0.32 & 5 \\
\hline & & & 20 & 57.0 & 12.6 & 0.2 & 0.00 & 0.00 & 7 \\
\hline & & & 30 & 17.1 & 15.2 & 0.9 & 0.10 & 0.56 & 6 \\
\hline & & & 40 & 5.1 & 14.8 & 2.9 & 0.00 & 0.00 & 7 \\
\hline & & & 50 & 5.1 & 19.5 & 3.8 & 0.01 & 0.24 & NA \\
\hline & & & 80 & 12.9 & 31.1 & 2.4 & 0.01 & 0.09 & 3 \\
\hline \multirow[t]{10}{*}{$36^{\circ} 29.94^{\prime} \mathrm{S}, 73^{\circ} 07.8^{\prime} \mathrm{W}, \mathrm{NUC}$} & Stn 18 & 15-Jan-03 & & & & & & & \\
\hline & MLD : & 30 & 0 & 879.3 & 28.6 & 0.03 & 1.6 & 0.19 & 1 \\
\hline & & & 5 & 519.9 & 32.5 & 0.10 & 1.6 & 0.32 & 1 \\
\hline & & & 10 & 800.7 & 37.5 & 0.05 & 1.0 & 0.13 & 8 \\
\hline & & & 15 & 628.2 & 32.9 & 0.10 & 3.7 & 0.59 & 9 \\
\hline & & & 20 & 440.7 & 19.3 & 0.04 & 2.1 & 0.47 & 6 \\
\hline & & & 30 & 267.0 & 42.0 & 0.20 & 1.4 & 0.54 & 1 \\
\hline & & & 40 & 23.4 & 56.6 & 2.4 & 0.8 & 3.51 & 1 \\
\hline & & & 50 & 12.0 & 33.1 & 2.8 & 0.8 & 6.85 & 1 \\
\hline & & & 80 & 14.4 & 49.5 & 3.4 & 0.8 & 5.71 & 0.5 \\
\hline \multirow[t]{5}{*}{$36^{\circ} 29.94$ 'S, $73^{\circ} 07.8^{\prime} \mathrm{W}, \mathrm{UC}$} & Stn 18 & *14-Feb-03 & & & & & & & \\
\hline & MLD : & 16 & 0 & 544.5 & 52.2 & 0.1 & 0.3 & 0.06 & 46 \\
\hline & & & 10 & 565.2 & 63.9 & 0.1 & 2.0 & 0.36 & 15 \\
\hline & & & 20 & 6.0 & 37.9 & 6.3 & 0.3 & 4.25 & 5 \\
\hline & & & 50 & 11.1 & 30.6 & 2.8 & 0.0 & 0.00 & 0.3 \\
\hline \multirow[t]{10}{*}{$36^{\circ} 30.040^{\prime} \mathrm{S}, 73^{\circ} 41.37^{\prime} \mathrm{W}, \mathrm{UC}$} & Stn 40 & 14-Feb-03 & & & & & & & \\
\hline & MLD : & 34 & 0 & 354.6 & 57.3 & 0.2 & 4.0 & 1.12 & 16 \\
\hline & & & 5 & 393.9 & 45.2 & 0.1 & 2.1 & 0.53 & 15 \\
\hline & & & 10 & 147.9 & 30.4 & 0.2 & 4.8 & 3.21 & 21 \\
\hline & & & 15 & 39.0 & 27.8 & 0.7 & 2.4 & 6.09 & 4 \\
\hline & & & 20 & 53.4 & 32.0 & 0.6 & 3.8 & 7.20 & NA \\
\hline & & & 30 & 21.0 & 29.2 & 1.4 & 3.5 & 16.63 & 5 \\
\hline & & & 50 & 19.2 & 29.6 & 1.5 & 1.7 & 9.10 & 17 \\
\hline & & & 75 & 3.0 & 17.6 & 5.9 & 0.5 & 16.30 & 4 \\
\hline & & & 100 & 3.6 & 16.4 & 4.5 & 0.2 & 5.82 & 0.7 \\
\hline \multirow[t]{10}{*}{$36^{\circ} 29.94^{\prime} \mathrm{S}, 73^{\circ} 07.8^{\prime} \mathrm{W}, \mathrm{UC}$} & Stn 18 & 15-Mar-03 & & & & & & & \\
\hline & MLD : & 15 & 0 & 9.3 & 27.0 & 2.9 & 1.9 & 20.94 & NA \\
\hline & & & 5 & 10.2 & 32.6 & 3.2 & 0.5 & 5.02 & NA \\
\hline & & & 10 & 24.3 & 21.5 & 0.9 & 0.2 & 0.83 & NA \\
\hline & & & 15 & 9.0 & 28.3 & 3.1 & 0.4 & 4.55 & NA \\
\hline & & & 20 & 10.2 & 42.4 & 4.2 & 0.1 & 1.00 & NA \\
\hline & & & 30 & 4.2 & 43.2 & 10.3 & 0.2 & 4.88 & NA \\
\hline & & & 40 & 3.6 & 32.1 & 8.9 & 0.2 & 5.69 & NA \\
\hline & & & 50 & 4.8 & 19.8 & 4.1 & 0.4 & 8.54 & NA \\
\hline & & & 80 & 6.6 & 48.9 & 7.4 & 0.0 & 0.00 & NA \\
\hline
\end{tabular}


Table 3

\section{Spearman's rank correlations coefficients (r), marked correlations are significant at $P<0.05$}

Coeficientes del rango de correlaciones de Spearman (r), las correlaciones en negrita son significativas a $P<0,05$

\begin{tabular}{lccccc}
\hline Variables & VP & BP & HNF & ANF & chl- $a$ \\
\hline VP & 1.00 & & & & \\
BP & $\mathbf{0 . 5 5}$ & 1.00 & & & \\
HNF & $\mathbf{0 . 5 4}$ & 0.30 & 1.00 & & \\
ANF & $\mathbf{0 . 6 7}$ & 0.28 & $\mathbf{0 . 4 7}$ & 1.00 & \\
chl- $a$ & $\mathbf{0 . 3 9}$ & 0.25 & 0.09 & $\mathbf{0 . 5 6}$ & 1.00 \\
\hline
\end{tabular}

proportion of the total phytoplankton biomass at Stn 18 during the first three sampling dates (i.e. 12-Dec-02, 15Jan-03 and 14-Feb-03) (Table 2). ANF increased their proportion from total $\mathrm{PH}$ at Stn 40, reaching values of $16.63 \%$ and at Stn 18 (15-Mar-03) represented 20.94\% of the total phytoplankton biomass (Table 2). MannWhitney U-test was used to assess significant differences between upwelling and non-upwelling conditions. Only VP abundance was significantly different $(P=0.04)$ between the sampling dates. The abundance of VP was significantly and positively correlated to the abundances of BP, HNF, and ANF ( $\mathrm{r}=0.55,0.54$ and $0.67, P<0.05$, Table 3) when considering all the data available at both stations $(n=30-32)$. The abundance of BP was not significantly correlated to the abundance of HNF or ANF, but HNF was significantly correlated to ANF abundance whereas chlorophyll- $a$ values were significantly correlated to VP and ANF abundances (Table 3). Estimates of VP/BP ratios in the water column (Table 2) varied between 1 and 46 at Stn 18 (average $=8$ ), and were between 0.7 to 21 for Stn 40 presenting an average of 12 (overall average $=9$ for all data).

\section{Discussion}

This study represents a first assessment of the distribution of microbial assemblages - from viruses to nanoflagellates - in association with the oceanographic variability in the Humboldt Current system (HCS) off Concepción and with respect to the inter-relationships between these various components. The significant relationship between VP and the other microbial components suggest that, during the upwelling season off Concepción, BP, HNF and ANF might be hosts of marine viruses. Among the few comparable results for upwelling regions, a strong correlation was also found between the abundance of VP and prokaryotes in Monterey Bay, California (Culley \&
Welschmeyer 2002). In other coastal regions (e.g. Northern Adriatic Sea and Gulf of Mexico), a significant correlation between VP and BP has been reported $(\mathrm{r}=$ 0.7 and 0.93, respectively) (Weinbauer et al. 1993, Weinbauer \& Suttle 1997). In addition, the high variability of VP abundance in this system may indicate high viral production and loss rates, as found by Jiang \& Paul (1994). In a comprehensive study, Wommack \& Colwell (2000) found that the ratio VP/BP generally falls between 3 and 10, the higher values being associated with more productive systems. Overall, bacterioplankton host populations produce greater number of viruses under environmental conditions that favour fast growth and high productivity (Wommack \& Colwell 2000). Ratios in the present study ranged between 0.7 and 46 (mean $=9$ ), suggesting a high degree of interaction between virioplankton and bacterioplankton communities in this highly productive upwelling system.

In terms of VP abundances in upwelling regions, the maximum value in the coastal zone of the California upwelling area (Culley \& Welschmeyer 2002) was one order of magnitude lower than the one in the present study, and also the integrated values were 4 orders of magnitude lower even when the integration depth was higher in the former. These differences may, at least in part, be explained by the fact that the California samples were taken during the non-upwelling season (end of summer beginning of autumn); it may also be linked to the higher productivity of the HCS coastal upwelling region $(>5 \mathrm{~g}$ $\mathrm{C} \mathrm{m}^{-2} \mathrm{~d}^{-1}$; Daneri et al. 2000). Compared with other coastal areas, our VP abundance values fell in the upper range reported in a review $\left(0.005-460 \times 10^{6} \mathrm{VLP}^{-1}\right)$ by Wommack \& Colwell (2000). In general, VP abundances reported after $\left(1.5 \times 10^{7} \mathrm{VLP}^{-1}\right)$ an during $\left(7 \times 10^{7}\right.$ VLP $\mathrm{mL}^{-1}$ ) an upwelling event off Valparaíso Bay (Kuznar et al. 2009) were in the same order of magnitude than the ones found during this study and coincidently the highest VP abundances were presented during upwelling. $\mathrm{BP}$ abundances during the present study were within the same order of magnitude than those reported for other upwelling systems $\left(0.02-14 \times 10^{6}\right.$ cells $\left.\mathrm{mL}^{-1}\right)$ (Brown et al. 1991, Painting et al. 1993, Wiebinga et al. 1997, Garrison et al. 2000, Culley \& Welschmeyer 2002), and with respect to the values previously described for the HCS region (0.1-4 x $10^{6}$ cells $\mathrm{mL}^{-1}$ ) (Sorokin \& Kogelschatz 1979, McManus \& Peterson 1988, Pacheco \& Troncoso 1998, Pantoja et al. 1989, Cuevas et al. 2004). In terms of bacterioplankton biomass the values reported here, are higher than the ones reported for spring period 2004 at the same stations (i.e. 0.3 to 1.6 and 0.08 to $0.5 \mathrm{~g} \mathrm{C} \mathrm{m}^{-2}$ for Stn 18 and 40 respectively) (Vargas et al. 2007). Probably due to the sampled stations were more 
influenced by upwelling during this campaign. On the other hand cyanobacteria biomass was low in comparison with the other microbial components, same as reported by Vargas et al. (2007).

The abundances of HNF reported here were within the lower range $\left(<1 \times 10^{3}\right.$ cells $\left.\mathrm{mL}^{-1}\right)$ of previous observations during the upwelling season in the area (McManus \& Peterson 1988, Cuevas et al. 2004). The same tendency was observed for biomass values that were 2 to 4 order of magnitude lower than the ones reported for the same area during spring/summer 2004-2005 (Vargas et al. 2007). In comparison with the previous values described for the area off Concepción, the present ANF abundance values were lower 6 times (10-20 x 105 cells $\mathrm{mL}^{-1}$, Cuevas et al. 2004). Overall, the heterotrophic bacteria biomass represented a large proportion of the microbial community in the upwelling system off Concepción during this study. However, BP to phytoplankton biomass ratio clearly shows that, during upwelling conditions, large phytoplankton dominate the autotrophic biomass although, in the Arabian Sea upwelling system, the autotrophic biomass (43-64\%) contributed with a similar proportion as the heterotrophic bacteria (16-44\%) (Garrison et al. 2000). On the other hand, bacterial biomass remained low during all the sampling period (i.e. winter 2004 to autumn 2005) for the same inshore and offshore stations, what was explained by a top-down control carried out by HNF (Vargas et al. 2007).

The association between microbial abundances and oceanographic variability (including active upwelling vs. non-upwelling conditions) during the present study was, in general, poor. Only VP abundances seem to be influenced by upwelling conditions, same as shown in Valparaíso Bay where upwelling conditions had an effect on VP abundances (Kuznar et al. 2009). This was due, partially, to the low temporal variability in some of the variables (temperature, salinity) and to the small data set available. In the area of study, salinity changes can be large in response to the influence of precipitation (winter) and river runoff (winter-spring), with the formation of a thin (<10 m depth) fresher-water layer (Faúndez-Báez et al. 2001). Hence, a greater influence of this factor can be expected on a seasonal basis rather than between upwelling events. In other coastal systems, a negative relationship has been observed between VP abundance and salinity (Paul et al. 1993, Weinbauer et al. 1993). The most clear relationships between the abundances of microbial assemblages and oceanographic conditions was that related to oxygen vertical distribution, demarked by the presence of a strong oxycline with suboxic waters below, at a relatively shallow depth $(<20 \mathrm{~m})$. Contrary to our findings, VP abundance in the Chesapeake Bay was not related to oxygen levels (Wommack et al. 1992) while, in the Cariaco Basin, VP in the anoxic waters were as numerically important as they were in oxic waters (Taylor et al. 2003) and, in the Baltic sea, VP and BP abundances increased in anoxic waters (Weinbauer et al. 2003). However, a pattern of higher BP and protozoa biomasses in surface oxygenated waters was also found in the upwelling area off Peru (Sorokin \& Kogelschatz 1979). Also, this pattern was observed for HNF biomass in a Danish fjord (Fenchel et al. 1990), with anoxic waters below the oxycline, but BP abundance was relatively constant in the water column while BP biomass was higher in the anoxic layer. In contrast to our data set, BP abundance and secondary production in various lakes were significantly greater in anoxic than in oxic waters due, according to the authors, to larger bacterial populations growing slightly more slowly than aerobic bacteria (Cole \& Pace 1995).

In the coastal upwelling system off Concepción, McManus \& Peterson (1988) found greater abundances of HNF and BP during periods of stratification as compared to active upwelling conditions, though not in a consistent manner; in the present study, this observation was only applicable to HNF integrated abundance and biomass. Off Perú, Sorokin \& Kogelschatz (1979) reported that the main components of the freshly upwelled waters were the micro-heterotrophs. During two contrasting seasons, Cuevas et al. (2004) observed similar abundances of BP and HNF during spring (upwelling) and winter cruises (non-upwelling) in the coastal area off Concepción. VP were the only microbial components that showed significant differences between upwelling and non-upwelling sampling dates, what might be explained by the differences in the host assemblages composition, that has been shown to change between upwelling and non-upwelling seasons (Cuevas et al. 2004, Vargas et al. 2007).

It was a striking result of this study to found no significant relationship between VP abundance and chl$a$ as independent variable, although we found a certain correlation between them. A similar result has been reported for the California upwelling system, between VP and chl-a (Culley \& Welschmeyer 2002). In larger data sets, however, a significant relationship existed, and is expected, between these variables (Maranger \& Bird 1995, Gasol \& Duarte 2000, Wommack \& Colwell 2000). One explanation for the lack of a dependence relationship during this study might be that the viruses were mostly associated with small rather than with large phytoplankton hosts (high chl- $a$ values implying a dominance of large cells). Similarly, it was not observed a significant 
relationship between BP abundance and chl- $a$, in contrast to other studies carried out in the same area during upwelling season (Cuevas et al. 2004, Troncoso et al. 2003). These studies reported a significant relationship between chl- $a$ and BP abundance $(\mathrm{r}=0.66$; Cuevas et al. 2004) and BP biomass ( $\mathrm{r}=0.19$; Troncoso et al. 2003). The authors suggested that substrate availability rather than grazing pressure was the main control of BP abundance and activity, at least during the upwelling period.

In addition, Vargas et al. (2007) found that HNF grazing estimates were 25 to 80 bacteria $\mathrm{HNF}^{-1} \mathrm{~h}^{-1}$, what could keep bacterial biomass relatively low all the year around in this upwelling system. Through viral lysis, it has been estimated that marine viruses kill $\sim 20-40 \%$ of marine bacteria on a daily basis (Suttle 1994) and contribute to microbial mortality at a similar level that grazing by zooplankton (Fuhrman \& Noble 1996). Therefore, the significant correlation between VP and the other components of the microbial assemblages that was found during this study, may suggest that viruses could be playing another type of top-down control in this upwelling system.

No doubt, the relationships among microbial distribution and oceanographic variables, as well as the inter-actions between their different components in the HCS require further investigations.

\section{Acknowledgments}

We thank F. Echeverría (DEFAO, UdeC) for providing the wind data from the Bellavista station; Dr. W. Schneider, L. Bravo and C. Hormazabal (COPAS, UdeC) for CTD-OF data; Dr. O. Ulloa and G. Alarcón (COPAS, $\mathrm{UdeC}$ ) for chlorophyll- $a$ data; and Dr. L. Farías (COPAS, $\mathrm{UdeC}$ ) for dissolved oxygen data. We also acknowledge the personnel of the R/V Kay-Kay for assistance in the field. This research was fully funded by the FONDAP Program (CONICYT, Chile) awarded for the COPAS Center (project $\mathrm{N}^{\mathrm{o}}$ 1500007).

\section{Literature cited}

Azam F. 1998. Microbial control of oceanic carbon flux: the plot thickens. Science 280: 694-696.

Bergh O, KY Borsheim, G Bratbak \& M Heldal. 1989 High abundance of viruses found in aquatic environments. Nature 340: 467-468.

Børsheim KY \& G Bratbak. 1987. Cell volume to cell carbon conversion factor for a bacterivorous Monas sp. enriched from seawater. Marine Ecology Progress Series 36: 171-175.

Brown PC, SJ Painting \& KL Cochrane. 1991. Estimates of phytoplankton and bacterial biomass and production in the northern and southern Benguela ecosystems. South African Journal of Marine Science 11: 537-564.

Cole JJ \& ML Pace. 1995. Bacterial secondary production in oxic and anoxic freshwaters. Limnology and Oceanography 40: 1019-1027.

Cotner JB \& BA Biddanda. 2002. Small players, large role: microbial influence on biogeochemical processes in pelagic aquatic ecosystems. Ecosystems 5: 105-121.

Chrzanowski TH \& K Simek. 1990. Prey-size selection by freshwater flagellated protozoa. Limnology and Oceanography 35: 1429-1436.

Cuevas LA, G Daneri, B Jacob \& P Montero. 2004. Microbial abundance and activity in the seasonal upwelling area off Concepción $\left(\sim 36^{\circ} \mathrm{S}\right)$, central Chile: a comparison of upwelling and non-upwelling conditions. Deep-Sea Research II 51: 2427-2440.

Culley AI \& NA Welschmeyer. 2002. The abundance, distribution, and correlation of viruses, phytoplankton, and prokaryotes along a Pacific Ocean transect. Limnology and Oceanography 47: 1508-1513.

Daneri G, V Dellarossa, RA Quiñones, B Jacob, P Montero \& O Ulloa. 2000. Primary production and community respiration in the Humboldt Current System off Chile and associated oceanic areas. Marine Ecology Progress Series 197: 41-49.

Faúndez-Báez P, CE Morales \& D Arcos. 2001. Spatial and temporal variability of winter hydrography in the bay system off the VIII region (central-south Chile). Revista Chilena de Historia Natural 74: 817-831.

Fenchel T, LD Kristensen \& L Rasmussen. 1990. Water column anoxia: vertical zonation of planktonic protozoa. Marine Ecology Progress Series 62: 1-10.

Fuhrman JA. 1999. Marine viruses and their biogeochemical and ecological effects. Nature 399: 541-548.

Fuhrman JA \& RT Nobel. 1996. Viruses and protists cause similar bacterial mortality in coastal seawater. Limnology and Oceanography 40: 1236-1242.

Garrison DL, MM Gowing, MP Hughes, L Campbell, DA Caron, MR Dennet, A Shalapyonok, RJ Olson, MR Landry, SL Brown, H Liu, F Azam, GF Steward, HW Ducklow \& DC Smith. 2000. Microbial food web structure in the Arabian Sea: a US JGOFS study. Deep-Sea Research II 47: 1387-1422.

Gasol JM \& CM Duarte. 2000. Comparative analyses in aquatic microbial ecology: how far do they go? FEMS Microbiology Ecology 31: 99-106.

Hara S, K Terauchi \& Y Koike. 1991. Abundance of viruses in marine waters: assessment by epifluorescence and transmission electron microscopy. Applied Environmental Microbiology 57: 2731-2734.

Hennes KP \& CA Suttle. 1995. Direct counts of viruses in natural waters and laboratory cul-tures by epifluorescence microscopy. Limnology and Oceanography 40: 1050-1055. 
Jiang SC \& JH Paul. 1994. Seasonal and diel abundance of viruses and occurrence of lysogeny/bacteriocinogeny in the marine environment. Marine Ecology Progress Series 142: 163-172.

Kuznar J, JC Espinoza, S Avaria, M Valenzuela, C Pavez \& M Egaña. 2009. Microbiological effects produced by a coastal upwelling off central Chile. Revista de Biología Marina y Oceanografía 44: 189-196.

Maranger R \& DF Bird. 1995. Viral abundance in aquatic systems: a comparison between marine and fresh waters. Marine Ecology Progress Series 121: 217-226.

McManus GB \& WT Peterson. 1988. Bacterioplankton production in the nearshore zone during upwelling off central Chile. Marine Ecology Progress Series 43: 11-17.

Montecino V, PT Strub, FP Chavez, AC Thomas, J Tarazona \& T Baumgartner. 2006. Bio-physical interactions off western South America. In: Robinson AR \& KH Brink (eds). The Global Coastal Ocean: Interdisciplinary Regional Studies and Syntheses. The Sea 14: 1-69. Harvard University Press, Cambridge.

Morales CE, M Braun, H Reyes, JL Blanco \& AG Davies. 1996. Anchovy larval distribution in the coastal zone off northern Chile: the effect of low dissolved oxygen concentrations and of a cold-warm sequence (1990-95). Investigaciones Marinas, (Chile) 24: 77-96.

Munn CB. 2006. Viruses as pathogens of marine organismsfrom bacteria to whales. Journal of the Marine Biological Association of the United Kingdom 86: 453-467.

Pacheco A \& VA Troncoso. 1998. Bacterial cell size, abundance and bacterioplankton productivity in Concepción Bay, Chile: a Lagrangian design. Gayana Oceanológica 6: 3548.

Painting SJ, MI Lucas, WT Peterson, PC Brown, L Hutchings \& BA Mitchell-Innes. 1993. Dynamics of bacterioplankton communities during the development of an upwelling plume in the southern Benguela. Marine Ecology Progress Series 35: 35-53.

Pantoja S, H González \& P Bernal. 1989. Bacterial biomass and production in a shallow bay. Journal of Plankton Research 11: 599-604.

Paul JH, JB Rose, SC Jiang, CA Kellog \& L Dickson. 1993. Distribution of viral abundance in the reef environment of Key Largo, Florida. Applied Environmental Microbiology 59: 718-724.

Porter KG \& TS Feig. 1980. The use of DAPI for identifying and counting aquatic microflora. Limnology and Oceanography 25: 943-948.

Proctor LM \& JA Fuhrman. 1990. Viral mortality of marine bacteria and cyanobacteria. Nature 343: 60-62.

Riemann B, P Simonsen \& L Stensgaard. 1989. The carbon and chlorophyll content of phytoplankton from various nutrient regimes. Journal of Plankton Research 11: 11091116.
Sievers H \& N Silva. 1982. Masas de agua y circulación geostrófica frente a la costa de Chile, latitudes $18^{\circ} \mathrm{S}$ y $33^{\circ} \mathrm{S}$ (Operación Oceanográfica MARCHILE VII). Ciencia y Tecnología del Mar 6: 61-99.

Silva N. 1983. Masas de agua y circulación en la región del norte de Chile, latitudes $18^{\circ} \mathrm{S}-32^{\circ} \mathrm{S}$ (Operación Oceanográfica MARCHILE XI-ERFEN II). Ciencia y Tecnología del Mar 7: 47-84.

Silva N \& D Konow. 1975. Contribución al conocimiento de las masas de agua en el pacífico Sud-Oriental. Expedición KRILL. Crucero 3-4, julio-agosto 1974. Revista de la Comisión Permanente del Pacífico Sur 3: 63-75.

Simon N \& F Azam. 1989. Protein content and synthesis rate of planktonic bacteria. Marine Ecology Progress Series 51: 201-213.

Sobarzo MA. 1994. Oceanografía física entre Punta Nugurne

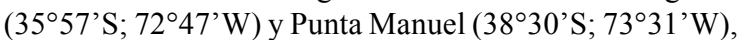
Chile: una revisión histórica (1936-1990). Gayana Oceanológica 2: 5-17.

Sorokin YI. 1978. Description of primary production and of the heterotrophic microplankton in the Peruvian upwelling region. Marine Biology 18: 62-71.

Sorokin Y \& JE Kogelschatz. 1979. Analysis of heterotrophic microplankton in an upwelling area. Hydrobiologia 66: 195208.

Strickland JDH. 1960. Measuring the production of marine phytoplankton. Bulletin Fisheries Research Board of Canada 122: 1-172.

Suttle CA. 1994. The significance of viruses mortality in aquatic microbial communities. Microbial Ecology 28: 237243.

Suttle CA. 2005. Viruses in the sea. Nature 437: 356-361.

Suttle CA. 2007. Marine viruses - major players in the global ecosystem. Nature Reviews, Microbiology 5: 801-812.

Taylor GT, C Hein \& M Iabichella. 2003. Temporal variations in viral distributions in the anoxic Cariaco Basin. Aquatic Microbial Ecology 30: 103-116.

Thiel M, EC Macaya, E Acuña, WE Arntz, H Bastias, K Brokordt, PA Camus, JC Castilla, LR Castro, M Cortés, CP Dumont, R Escribano, M Fernandez, JA Gajardo, CF Gaymer, I Gomez, AE González, HE González, PA Haye, JE Illanes, JL Iriarte, DA Lancellotti, G LunaJorquera, C Luxoro, PH Manriquez, V Marín, P Muñoz, SA Navarrete, E Pérez, E Poulin, J Sellanes, HH Sepúlveda, W Stotz, F Tala, A Thomas, CA Vargas, JA Vásquez \& A Vega. 2007. The Humboldt Current system of Northern-Central Chile oceanographic processes, ecological interactions and socioeconomic feedback. Oceanography and Marine Biology: an Annual Review 45: 195-345

Troncoso VA, G Daneri, LA Cuevas, B Jacob \& P Montero. 2003. Bacterial carbon flow in the Humboldt Current System off Chile. Marine Ecology Progress Series 250: 112. 
Vargas CA, RA Martinez, LA Cuevas, MA Pavez, C Cartes, HE González, R Escribano \& G Daneri. 2007. The relative importance of the microbial and classical foods webs in a highly productive coastal upwelling area. Limnology and Oceanography 52: 1495-1510.

Watson SW, TJ Novitsky, HL Quinby \& FW Valois. 1977. Determination of bacterial number and biomass in the marine environment. Applied Environmental Microbiology 33: 940-946.

Weinbauer MG \& CA Suttle. 1997. Comparison of epifluorescence and transmission electron microscopy for counting viruses in natural marine waters. Aquatic Microbial Ecology 13: 225-232.

Weinbauer MG, D Fuks \& P Peduzzi. 1993. Distribution of viruses and dissolved DNA along a coastal trophic gradient in the northern Adriatic Sea. Applied Environmental Microbiology 59: 4074-4082.

Weinbauer MG, I Brettar \& MG Höfle. 2003. Lysogeny and virus-induced mortality of bacterioplankton in surface, deep, and anoxic marine waters. Limnology and Oceanography 48: 1457-1465.

Wiebinga CJ, MJW Veldhuis \& HJW De Baar. 1997. Abundance and productivity of bacterioplankton in relation to seasonal upwelling in the northwest Indian Ocean. DeepSea Research Part I 44: 451-476.

Wommack KE \& RR Colwell. 2000. Virioplankton: viruses in aquatic ecosystems. Microbiology and Molecular Biology Reviews 64: 69-114.

Wommack KE, RT Hill, M Kessel, E Russek-Cohen \& RR Colwell. 1992. Distribution of viruses in the Chesapeake Bay. Applied Environmental Microbiology 58: 2965-2970.

Xenopoulus MA \& DF Bird. 1997. Virus à la sauce Yo-Pro: Microwave-enhanced staining for counting viruses by epifluorescence microscopy. Limnology and Oceanography 42: 1648-1650.

Zar JH. 1999. Biostatistical analysis, 663 pp. Prentice Hall, Englewood Cliffs.

Recibido el 14 de abril de 2009 y aceptado el 07 de octubre de 2009 